\title{
Land Use Changes and its Driving Factors in a Coastal Zone
}

\author{
Xuncheng Fan ${ }^{1}$, Lili Zhao ${ }^{1}$, Dongjin $\mathrm{He}^{2 *}$ \\ ${ }^{1}$ College of Urban and Rural Construction, Shaoyang University, Shaoyang, China \\ ${ }^{2}$ Forestry College, Fujian Agriculture and Forestry University, Fuzhou, China
}

Received: 23 February 2019

Accepted: 14 April 2019

\begin{abstract}
Three-fifths of the world's population lives in coastal zones. The rapid increase of the population in the zone is bound to have a significant impact on the ecological environment, thus affecting economic sustainable development. Therefore, a coastal zone was regarded as the study area, and we studied the land use changes and its driving factors in the zone. The study had an important guiding significance for the scientific management and sustainable development of land in zones. Firstly, object-oriented classification was used as the classification method of land use. Secondly, the dynamic degree of land use and canonical correlation analysis were used to study the land use changes and its driving factors. The results showed that forestland and grassland, and cultivated land were the main types of land use in the study area over the study period. The area of forestland, grassland and aquaculture increased while the area of cultivated land decreased. The area of aquaculture and unused land has dramatically changed over the study period. Population was the main driving factor for the areal change of construction land, water and unused land. The main driving factors of aquaculture were population and primary industry. Population and policy were the main driving factors of cultivated land. Policy was the main driving factor causing the change of forestland and grassland. Consequently, policy, population and primary industry were the main drivers of land use changes in the coastal zone.
\end{abstract}

Keywords: dynamic degree, canonical correlation analysis, Ningde, RS, GIS

\section{Introduction}

Land is a natural complex that includes geology, geomorphology, climate, hydrology, soil, vegetation and other natural elements [1-2]. Land use means that human beings manage and treat land, adopting a series of biological and technological means according to natural characteristics of land and economic purposes during the long term [3-4]. Land use changes not only change the structure of the Earth's surface, but also affect the ecosystem and humans. Therefore, the International Geosphere-Biosphere Program (IGBP) and the International Human Dimensions Program on Global Environmental Change (IHDP) jointly proposed a scientific research program about land use changes and regarded this program as a core of global change research [5]. The study of driving factors is an important part of land use change research [6-7]. It has an outstanding practical significance for the accurate prediction for the future of land use changes and rational planning of regional land, and environment protection to identify the driving factors. 
The coastal zone refers to the region of interaction between land and sea [8-9]. It not only is affected by natural factors, but also by human activities. Therefore, the balance in the ecosystem of the coastal zone is easily broken. The area of the global coastal zone is less than $20 \%$ of the earth's surface. However,3/5 of the world's population lives in coastal zones [10]. In this study, the population in the coastal zone of Ningde City accounted for $68 \%$ of the total population of Ningde by the end of 2014 [11]. In addition, the primary productivity of coastal zone accounts for a quarter of the world's primary productivity, and $95 \%$ of fishing activity is carried out in coastal ecosystems [12]. Therefore, coastal zones are one of the most promising areas for human beings, and are also an extremely fragile and sensitive region. Study of land use changes in a coastal zone provided an important theoretical support for the sustainable development of a coastal zone.

The coastal zone of Ningde, the study area, is located in the middle of the coastline of China's mainland. There are more than 600 kinds of aquatic resources in this zone. The impact of human activities on the coastal zone has become increasingly serious with economic development, population growth, and urbanization. The existing research about this region mainly focused on the landscape changes of the wetland in a coastal zone [13], the distribution characteristics of heavy metals in different wetland types [14], the phenotypic plasticity of invasive species (Spartina alterniflora) [15], and ecological security of the zone [16]. There is alack of research on land use changes and its driving factors in the coastal zone. Therefore, land use changes and its driving factors in the zone were studied using a dynamic degree of land use and canonical correlation analysis under support of RS and GIS. This study provided an important case for land management and policy formulation in a coastal zone.

\section{Materials and Methods}

\section{Choice and Overview of Study Area}

At present, the explanation of coastal zone is diverse. Geomorphologists believe that a coastal zone should be the intertidal zone between the high and low tides [17]. Some planners believe that part of the land in a coastal zone should not be bound, and the part of the sea should be extended to the continental shelf [18]. However, the administrative region (Jiaocheng, Fuan, Fuding, Xiapu) was regarded as the study area (Fig. 1). The main reason is that these regions directly contact the sea. Other reasons are that socio-economic factors were easily obtained from the statistical yearbook, which is measured in the administrative region.

The coastal zone of Ningde belongs to Fujian Province of China, which is located in the middle of the Yangtze River Delta, Pearl River Delta and Taiwan. The terrain is mainly hilly and mountainous. It belongs to the mid-subtropical maritime monsoon climate. The land area of the coastal zone is $6253 \mathrm{~km}^{2}$. The sea area is $44,600 \mathrm{~km}^{2}$, accounting for $35.63 \%$ of the total marine fishery area of the province. The coastline (excluding islands) is $943.2 \mathrm{~km}$ long, accounting for $28.35 \%$ of the total coastline of the province. The zone is rich in aquatic resources and has more than 600 kinds of marine life. It is rich in large yellow croaker, prawn, grouper, dioxin and sword. The artificial breeding and

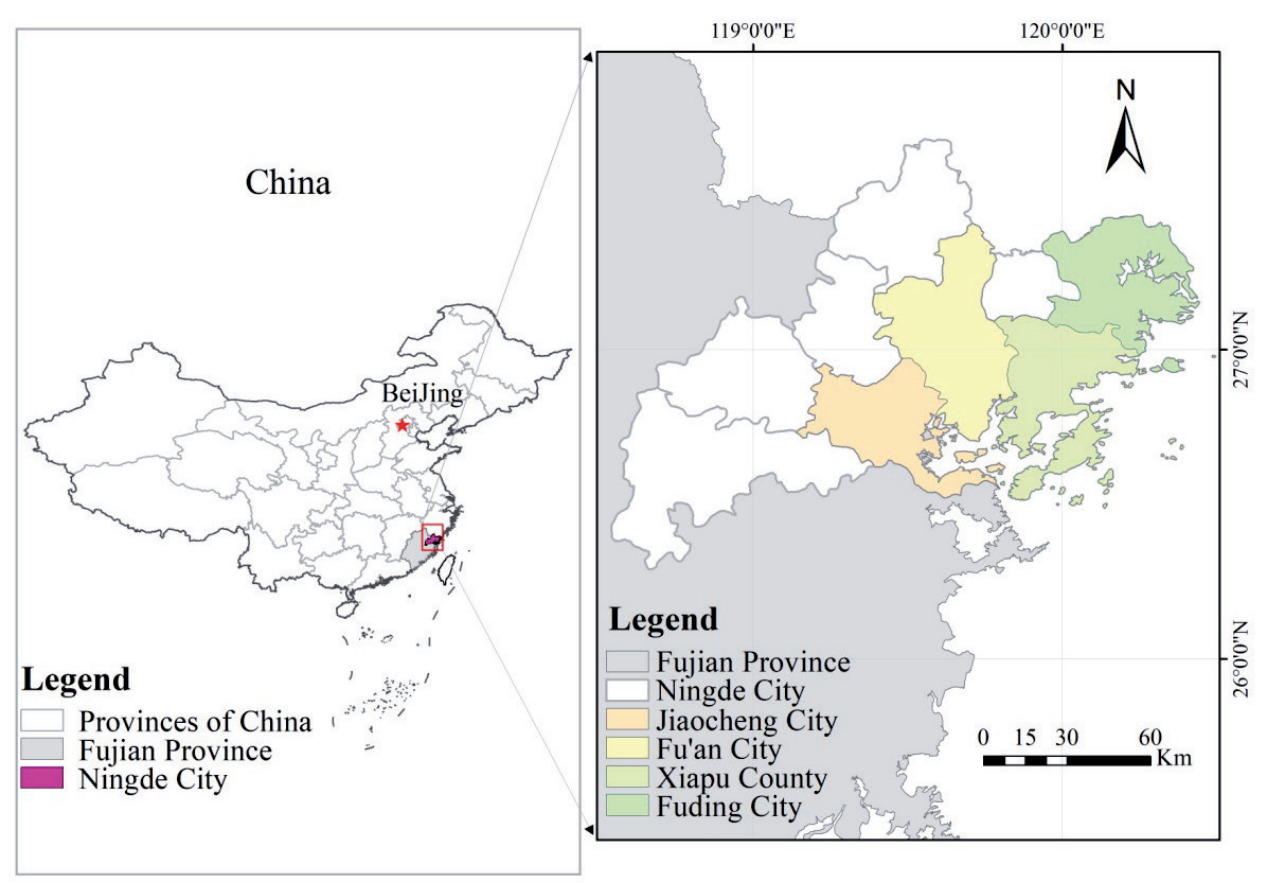

Fig. 1. Map of study area. 
Table 1. Source and description of the remote sensing data.

\begin{tabular}{|c|c|c|}
\hline Source & Shooting time & Description \\
\cline { 1 - 2 } Landsat-5 TM & $2000-05$ & \multirow{2}{*}{$\begin{array}{c}\text { The cloud coverage of these images was less than } 10 \% \text {. The four scenes were required to } \\
\text { completely cover the entire study area. Their track numbers were 119/42, 119/41, 118/41, } \\
\text { and } 118 / 42, \text { respectively. }\end{array}$} \\
\cline { 1 - 2 } Landsat-5 TM & $2009-06$ & $\begin{array}{r}\text { Landsat-8 OLI } \\
\text { and }\end{array}$ \\
\hline
\end{tabular}

seedling technology of large yellow croakers in the zone has reached the international leading level. At the end of 2014, the resident population and GDP of the coastal zone were 2.30 million and 137.60 billion yuan respectively.

\section{Source and Process of Data}

The remote sensing data, including Landsat-5 TM (2000 and 2009) and Landsat-8 OLI (2014) (Table1), were obtained from the Geospatial Data Cloud (http:// www.gscloud.cn/). In addition, other study materials include the administrative zoning maps obtained by the geographical information monitoring cloud platform (http://www.dsac.cn/) and the Ningde statistical yearbook from 2000 to 2014 [11,19-20].

These remote sensing images had undergone the correction of ground control point geometry and DEM terrain before being downloaded. Therefore, the processing of remote sensing data in this study was to do color synthesis, mosaic, clip and object-oriented classification using ENVI 5.2. Types of land use were divided into six categories: forestland and grassland, cultivated land, water, aquaculture, construction land, and unused land. In this study, remote sensing images from Landsat-5 TM and Landsat-8 OLI were processed using 4, 3, and 2 bands and 5, 4, and 3 bands for color synthesis respectively. Finally, the maps of land use classification were obtained using ENVI 5.2 (Fig. 2).

250 samples for each type of land use were selected to achieve better classification results. Field investigations and interactive verification using Google Earth were carried out. After field verification, the classification accuracy of the remote sensing images fromthe three periods was $89.30 \%, 94.50 \%$, and $92.50 \%$ respectively, which can meet the requirements of this study.

\section{Dynamic Degree of Land Use}

The land use dynamic degree reflects dynamic change of a specific land use type during the study period [21]. The mathematical model is as follows:

$$
K=\frac{U_{b}-U_{a}}{U_{a}} \times \frac{1}{T} \times 100 \%
$$

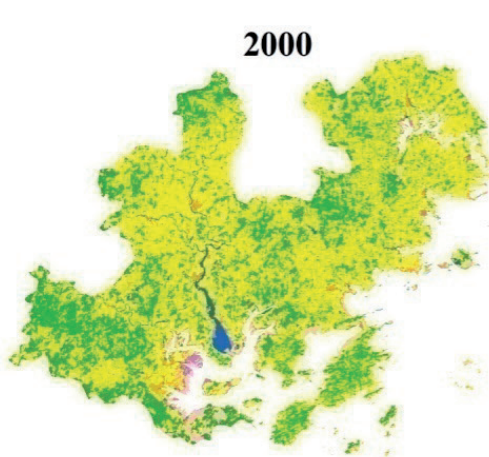

2014

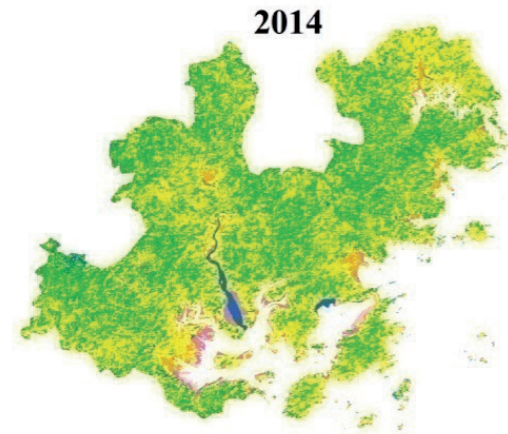

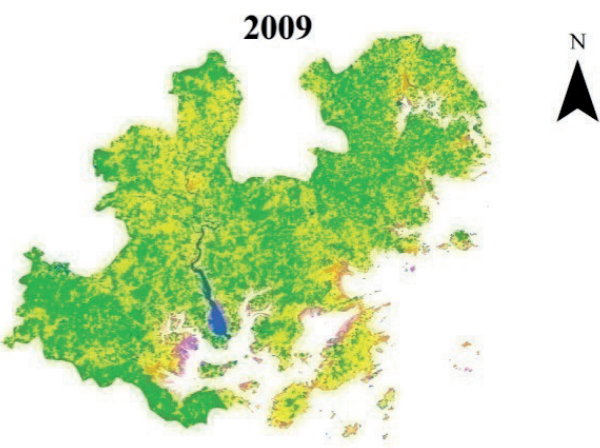

Legend

Forestland and grassland

Cultivated land

Water

Aquaculture

Construction land

Unused land

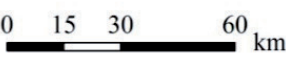

Fig. 2.Classification of land use types. 
...where $K$ is a value of dynamic degree of a specific land type; $U_{a}$ and $U_{b}$ represent the area of a specific land type at the beginning and end, respectively; and $T$ indicates the length of study, and its unit is a.

\section{Canonical Correlation Analysis}

Canonical correlation analysis is a multivariate statistical analysis method that reflects the overall correlation between the two sets of indicators using the correlation between pairs of integrated variables. For example, $\mathrm{U}_{1}$ and $\mathrm{V}_{1}$ are the linear combination of each variable in the two variable groups respectively. The two integrated variables $U_{1}$ and $V_{1}$ are extracted from the two sets of variables respectively in order to grasp the correlation between the two sets of indicators. Finally, the correlation between the two integrated variables is used to reflect the overall correlation between the two sets of indicators [22-23]. Land use changes and its driving factors can be quantitatively analyzed and simulated using the method. Therefore, it has been applied to study driving factors of land use changes by many scholars [24-25].

The socio-economic factors were used in principal component analysis. In the shorter period (14 years in this paper), the influence of natural factors on land use changes was not obvious. By contrast, the socioeconomic factors had a significant impact on land use changes in the shorter period [26]. The coastal zone in
Ningde is located in the middle of the Yangtze River Delta, the Pearl River Delta and Taiwan. The socioeconomic factors formed by the economy, population and urbanization had a greater impact on land use changes. Therefore, the socio-economic factors excluding natural factors were used to study the driving factors in the coastal zone.

Socio-economic factors were obtained using the Ningde Statistical Yearbooks from 2000, 2009 and 2014 [11,19-20]. Finally, 18 factors that were easy to be quantified and had a strong correlation with land use changes were selected. They included population, economy, consumption, technology and social awareness (Table 2). For canonical correlation analysis,these 18 factors were regarded as explanatory variables, and the areas of all the land use types obtained by remote sensing images were regarded as target variables.

However, multi-collinearity analysis was performed before using a canonical correlation analysis. Since these 18 explanatory variables might have strong correlation, multi-collinearity analysis was used to find the factors that can best represent the explanatory variables to improve the efficiency of the operation. Therefore, SPSS20.0 was used to perform multicollinear analysis. From Table 3, total population $\left(\mathrm{X}_{2}\right)$, urban population $\left(\mathrm{X}_{3}\right)$, population density $\left(\mathrm{X}_{4}\right)$, rural population $\left(\mathrm{X}_{5}\right)$, primary industry $\left(\mathrm{X}_{7}\right)$, local fiscal revenue $\left(\mathrm{X}_{12}\right)$, and natural population growth rate ( $\mathrm{X}_{18}$ ) passed a significance test with a significance level

Table 2. Selection of explanatory and target variables.

\begin{tabular}{|c|c|c|c|c|}
\hline \multicolumn{3}{|c|}{ Explanatory variable (Socio-economic factor, X) } & \multicolumn{2}{|c|}{ Target variable (Area of land use types, Y) } \\
\hline \multirow{5}{*}{ Population } & $\mathrm{X}_{1}$ & Household registration & $\mathrm{Y}_{1}$ & Cultivated land \\
\hline & $\mathrm{X}_{2}$ & Total population & $\mathrm{Y}_{2}$ & Construction land \\
\hline & $\mathrm{X}_{3}$ & Urban population & $\mathrm{Y}_{3}$ & Water \\
\hline & $\mathrm{X}_{4}$ & Population density & $\mathrm{Y}_{4}$ & Forestland and grassland \\
\hline & $\mathrm{X}_{5}$ & Rural population & $\mathrm{Y}_{5}$ & Aquaculture \\
\hline \multirow{8}{*}{ Economy } & $\mathrm{X}_{6}$ & GDP & $\mathrm{Y}_{6}$ & Unused land \\
\hline & $\mathrm{X}_{7}$ & Primary industry & & \\
\hline & $\mathrm{X}_{8}$ & Secondary industry & & \\
\hline & $\mathrm{X}_{9}$ & Tertiary Industry & & \\
\hline & $\mathrm{X}_{10}$ & Industrial output & & \\
\hline & $X_{11}$ & Gross agricultural output value & & \\
\hline & $\mathrm{X}_{12}$ & Local fiscal revenue & & \\
\hline & $X_{13}$ & Local fiscal expenditure & & \\
\hline Technology & $\mathrm{X}_{14}$ & Fixed assets investment & & \\
\hline \multirow{3}{*}{ Consumption } & $\mathrm{X}_{15}$ & Total retail sales of social consumer goods & & \\
\hline & $X_{16}$ & Urban and rural residents' savings balance & & \\
\hline & $X_{17}$ & Average annual salary of all employees & & \\
\hline Social awareness & $\mathrm{X}_{18}$ & Natural population growth rate & & \\
\hline
\end{tabular}


Table 3. Results of multi-collinearity analysis.

\begin{tabular}{|c|c|c|c|c|}
\hline $\begin{array}{c}\text { Target } \\
\text { variable }\end{array}$ & $\begin{array}{c}\text { Explanatory } \\
\text { variable }\end{array}$ & $\begin{array}{c}\text { Standard regres- } \\
\text { sion coefficient }\end{array}$ & $\mathrm{t}$ & Sig. \\
\hline $\mathrm{Y}_{1}$ & $\mathrm{X}_{7}$ & -0.550 & -9.973 & 0.000 \\
\hline & $\mathrm{X}_{2}$ & 1.407 & 25.529 & 0.000 \\
\hline $\mathrm{Y}_{2}$ & $\mathrm{X}_{3}$ & 0.942 & 10.082 & 0.000 \\
\hline $\mathrm{Y}_{3}$ & $\mathrm{X}_{2}$ & 1.128 & 14.344 & 0.000 \\
\hline & $\mathrm{X}_{12}$ & -0.358 & -4.271 & 0.001 \\
\hline & $\mathrm{X}_{18}$ & 0.160 & 2.304 & 0.042 \\
\hline $\mathrm{Y}_{4}$ & $\mathrm{X}_{5}$ & 0.971 & 14.672 & 0.000 \\
\hline $\mathrm{Y}_{5}$ & $\mathrm{X}_{5}$ & 0.993 & 12.021 & 0.000 \\
\hline & $\mathrm{X}_{4}$ & -0.232 & -2.808 & 0.016 \\
\hline $\mathrm{Y}_{6}$ & $\mathrm{X}_{3}$ & 1.322 & 5.061 & 0.000 \\
\hline & $\mathrm{X}_{4}$ & -0.532 & -4.173 & 0.002 \\
\hline & $\mathrm{X}_{5}$ & -0.678 & -2.554 & 0.027 \\
\hline
\end{tabular}

Table 4. Result of the canonical correlation coefficients.

\begin{tabular}{|c|c|c|c|c|c|}
\hline Group & $\begin{array}{c}\text { Canonical } \\
\text { correlation } \\
\text { coefficients }\end{array}$ & Wilk's & Chi-SQ & DF & Sig. \\
\hline 1 & 0.999 & 0.000 & 138.463 & 42.000 & 0.000 \\
\hline 2 & 0.989 & 0.000 & 61.612 & 30.000 & 0.001 \\
\hline 3 & 0.956 & 0.007 & 35.083 & 20.000 & 0.020 \\
\hline 4 & 0.897 & 0.077 & 17.965 & 12.000 & 0.117 \\
\hline 5 & 0.774 & 0.393 & 6.543 & 6.000 & 0.365 \\
\hline 6 & 0.144 & 0.979 & 0.146 & 2.000 & 0.930 \\
\hline
\end{tabular}

of $<0.05$. Therefore, canonical correlation analysis was performed using only the above seven variables.

After the canonical correlation analysis was operated, the results were tested using a canonical correlation coefficient. From Table 4, the correlation coefficients of the first three groups were greater with a value of $0.999,0.989$, and 0.956 , respectively. Their significance probability value (Sig.) were all less than 0.05 , indicating that the first three groups of variables represented most of the original indicators, and also clearly and fully explained the corresponding variables. Finally, the three groups of variables were analyzed in this study.

\section{Results}

\section{Area of Land Use}

The areas of six kinds of land use types from 2000, 2009, and 2014 were obtained using ArcGIS10.1. From Table 5, forestland and grassland, and cultivated land accounted for more than $87 \%$ of the total area over 14 years. The area of forestland, grassland and aquaculture increased by $1047.23 \mathrm{~km}^{2}$ and $60.80 \mathrm{~km}^{2}$, respectively. By contrast, the remaining land use types showed a decreasing trend. Specifically, the area of cultivated land decreased by $959.45 \mathrm{~km}^{2}$ during the study period.

\section{Dynamic Degree of Land Use}

From Table 6, the absolute value of aquaculture dynamic degree was the greatest, with a value of $5.70 \% / \mathrm{a}$, indicating that aquaculture had the fastest change in area over 14 years. The absolute value of unused land was $4.71 \% / \mathrm{a}$, indicating that the change of unused land was faster than other land use types except aquaculture. The value of aquaculture reached $12.14 \%$ /a from 2000 to 2009 , while the value was only $-2.82 \%$ /a from 2009 to 2014 . This indicated that the area of aquaculture grew more rapidly from 2000 to 2009 .

\section{Driving Factors of Land Use Changes}

The canonical loadings were obtained after the operation of canonical correlation analysis. From Table 7 , the cultivated land, water area and construction land in target variables of the first group were extracted. The value of the canonical loadings in the three land use types were $-0.978,-0.945$, and -0.939 , respectively.

Table 5. Areas of six kinds of land use types $\left(\mathrm{km}^{2}\right)$.

\begin{tabular}{|c|c|c|c|c|}
\hline Land use types & 2000 & 2009 & 2014 & Changing value over the 14 years $\left(\mathrm{km}^{2}\right)$ \\
\hline Unused land & 119.11 & 64.30 & 40.63 & -78.48 \\
\hline Construction land & 219.82 & 247.70 & 211.63 & -8.19 \\
\hline Forestland and grassland & 1669.84 & 2892.25 & 2717.07 & 1047.23 \\
\hline Aquaculture & 76.24 & 159.57 & 137.04 & 60.80 \\
\hline Water & 277.25 & 332.44 & 215.34 & -61.91 \\
\hline Cultivated land & 3890.47 & 2556.47 & 2931.02 & -959.45 \\
\hline Total & 6252.73 & 6252.73 & 6252.73 & - \\
\hline
\end{tabular}


Table 6. Dynamic degree of land use types (\%/a).

\begin{tabular}{|c|c|c|c|}
\hline Land use types & $2000-2009$ & $2009-2014$ & $2000-2014$ \\
\hline Unused land & -5.11 & -7.36 & -4.71 \\
\hline Construction land & 1.41 & -2.91 & -0.27 \\
\hline $\begin{array}{c}\text { Forestland and } \\
\text { grassland }\end{array}$ & 8.13 & -1.21 & 4.48 \\
\hline Aquaculture & 12.14 & -2.82 & 5.70 \\
\hline Water & 2.21 & -7.04 & -1.59 \\
\hline Cultivated land & -3.81 & 2.93 & -1.76 \\
\hline
\end{tabular}

In the explanatory variable group of the first group, total population and urban population were extracted due to the value of -0.992 and -0.991 , respectively. It can be seen that there was a strong correlation between the change of cultivated land, construction land and water area from Y group, and the total population and urban population from $\mathrm{X}$ group.

From the second group, aquaculture from Y group and primary industry from $\mathrm{X}$ group were extracted based on the value of -0.525 and -0.582 . This indicated that the aquaculture was positively correlated with the primary industry. From the third group, unused land with a value of 0.474 and natural population growth rate with a value of -0.683 were extracted, indicating that the changes of unused land were negatively correlated with the natural population growth rate.

\section{Discussion}

The area of forestland and grassland increased, while the area of cultivated land decreased over the study period. This is mainly because forests in Ningde were used as a commodity under the supervision of the policy from the government. Increasing the area of forestland was regarded as a way to improve the local economy. In addition, cultivated land located in inappropriate areas was transformed into forestland under the supervision of the policy. Another reason for the decrease of cultivated land was the dramatic increase of the aquaculture area over the study period. The population of the coastal zone increased from 2.08 million in 2000 to 2.30 million in 2014. The people who live in seaside prefer to eat seafood. The increased population led to the increase in demand for seafood. Therefore, more cultivated land was transferred into the aquaculture.

The result of the canonical correlation analysis showed that there was a strong correlation between cultivated land, construction land, waters and unused land from $\mathrm{Y}$ group and the total population, urban population and natural population growth rate from $\mathrm{X}$ group. This indicated an increase in the population, resulting in the increasing demand for food, housing, drinking water, and the occupation of unused land. Consequently, the population is an important driving factor for the change of cultivated land, construction land, water and unused land. Wuet al. [27] studied the driving factors of land use change in the coastal zone

Table 7. Results of canonical loadings of the canonical correlation analysis.

\begin{tabular}{|c|c|c|c|c|c|c|c|}
\hline \multirow{2}{*}{$\begin{array}{l}\text { Canonical } \\
\text { variables }\end{array}$} & \multirow{2}{*}{ Name of variables } & \multicolumn{6}{|c|}{ Canonical loadings } \\
\hline & & Group 1 & Group 2 & Group 3 & Group 4 & Group 5 & Group 6 \\
\hline \multicolumn{8}{|c|}{ Target variable Y } \\
\hline $\mathrm{Y}_{1}$ & Cultivated land & $\underline{-0.978}$ & 0.156 & 0.103 & 0.038 & -0.035 & 0.070 \\
\hline $\mathrm{Y}_{2}$ & Construction land & $\underline{-0.939}$ & -0.132 & 0.045 & 0.181 & -0.21 & -0.147 \\
\hline $\mathrm{Y}_{3}$ & Water & $\underline{-0.945}$ & 0.018 & -0.225 & 0.22 & -0.075 & -0.049 \\
\hline $\mathrm{Y}_{4}$ & Forestland and grassland & -0.895 & -0.401 & -0.138 & 0.011 & 0.073 & -0.112 \\
\hline $\mathrm{Y}_{5}$ & Aquaculture & -0.822 & $\underline{-0.525}$ & -0.084 & 0.163 & -0.006 & 0.126 \\
\hline $\mathrm{Y}_{6}$ & Unused land & -0.61 & 0.12 & $\underline{0.474}$ & 0.532 & 0.317 & -0.072 \\
\hline \multicolumn{8}{|c|}{ Explanatory variable $\mathrm{X}$} \\
\hline $\mathrm{X}_{2}$ & Total population & $\underline{-0.992}$ & -0.123 & -0.029 & -0.016 & 0.01 & 0.014 \\
\hline $\mathrm{X}_{3}$ & Urban population & $-\underline{0.991}$ & -0.017 & 0.08 & -0.002 & -0.044 & 0.09 \\
\hline $\mathrm{X}_{4}$ & Population density & -0.177 & 0.096 & -0.386 & -0.78 & -0.12 & 0.305 \\
\hline $\mathrm{X}_{5}$ & Rural population & -0.897 & -0.374 & -0.193 & -0.084 & -0.09 & -0.011 \\
\hline $\mathrm{X}_{7}$ & Primary industry & -0.762 & $\underline{-0.582}$ & -0.235 & -0.099 & 0.088 & -0.042 \\
\hline $\mathrm{X}_{12}$ & Local fiscal revenue & -0.511 & -0.382 & 0.011 & -0.696 & 0.092 & -0.165 \\
\hline $\mathrm{X}_{18}$ & Natural population growth rate & -0.018 & -0.165 & $\underline{-0.683}$ & -0.209 & 0.205 & 0.251 \\
\hline
\end{tabular}


of Fujian Province, China from 2005 to 2015 under the support of RS and GIS, and found that population, social wealth, and technology were the main drivers in the zone. Han et al. [28] studied the driving factors in the coastal zone of the United States during 50 years. They found that population, economy and policy had the most significant impact on land use changes in the zone.Wang et al.[29] studied the driving factors in the coastal zone of Jiangsu province, China, and found that population growth, government policies and the economy were the main driving factors in the zone. In summary, the study results of other researchers also once again proved that population was one of the factors affecting land use changes in a coastal zone.

\section{Conclusions}

Forestland, grassland, and cultivated land occupied more than $87 \%$ of the study area. The area of forestland, grassland, and aquaculture increased, while the area of cultivated land decreased over the 14 years. The change of aquaculture area was the most dramatic during the 14 years, especially between 2000 and 2009. The area of unused land had the fastest decrease over the study period.

Policy was the driving factor for the change of the forestland, grassland, and cultivated land. The population and natural population growth rate were the driving factors for the change of land use. Population and primary industry were the drivers of change in aquaculture. In summarize, policy, population, and primary industry were the main drivers of land use changes in the coastal zone.

\section{Acknowledgements}

This work was supported by the Specialized Research Fund forthe Doctoral Program of Shaoyang University (fund No. 17ZX03) and research project No. 2015N0018 sponsored by the Fujian Provincial Department of Science and Technology.

\section{Conflict of Interest}

The authors declare no conflict of interest.

\section{References}

1. WANG R., FENGL., DANH., LIB. L. Understanding ecocomplexity: social-economic-natural complex ecosystem approach. Ecological Complexity, 8 (1), 0,2011.

2. SKOLE D.L., JUSTICE C.O., TOWNSHEND J.R.G., JANETOS A.C. A land cover change monitoring program: strategy for an international effort. Mitigation \& Adaptation Strategies for Global Change, 2 (2-3), 157, 1997.
3. FOLEY J.A., RUTH D., ASNER G.P., CAROL B., GORDON B., CARPENTER S.R., STUART C.F., COE M.T., DAILY G.C., GIBBS H.K. Global consequences of land use. Science, 309 (5734), 570, 2005.

4. ZERMEÑO-HERNÁNDEZ I., PINGARRONI A., MARTÍNEZ-RAMOS M. Agricultural land-use diversity and forest regeneration potential in humanmodified tropical landscapes. Agriculture Ecosystems \& Environment, 230,210,2016.

5. BEURS K.M.D., HENEBRY G.M. Land surface phenology and temperature variation in the international geosphere-biosphere program high-latitude transects. Global Change Biology, 11 (5), 779, 2010.

6. ZHAO J.S., YUAN L., ZHANG M. A study of the system dynamics coupling model of the driving factors for multiscale land use change. Environmental Earth Sciences, 75 (6), 1, 2016.

7. FENG Y., TONG X. Using exploratory regression to identify optimal driving factors for cellular automaton modeling of land use change. Environmental Monitoring \& Assessment, 189 (10), 515, 2017.

8. CHYBICKI A., KULAWIAK M., ŁUBNIEWSKI Z. Characterizing surface and air temperature in the Baltic Sea coastal area using remote sensing techniques and gis. Polish Maritime Research, 23 (1), 3,2016.

9. ZHENG Y., YU G. Spatio-temporal distribution of vegetation index and its influencing factors - a case study of the Jiaozhou Bay, China. Chinese Journal of Oceanology and Limnology, 35 (6), 1398,2017.

10. ZHANG H., ZHOU L.G., CHEN M.N., MA W.C. Land use dynamics of the fast-growing Shanghai metropolis, China (1979-2008) and its implications for land use and urban planning policy. Sensors, 11 (2), 1794, 2011.

11. BUREAUN. S. Ningde Statistical Yearbook; China Statistics Press: Beijing, China, 5, 2014 [In Chinese].

12. ZHANG Y.G., HAN Z.L., LIU K., WANG D. Analysis of regional differences of marine economy and use structure of coastal zone: A case study of Liaoning Province. Geographical Research, 29 (1), 24, 2010.

13. HE D.J., LIN L., YOU W.B., WANG R., CAI J.B., LIAO X.J. Landscape pattern changes of coastal wetlands and its simulation in eastern Fujian Province. Journal of Fujian College of Forestry, 33 (2), 97, 2013.

14. ZHAO L.L., YOU W.B., HU H.Q., HONG W., LIAO X.J., XIAO S.H., WANG R., CAI J.B., FAN X.C., TAN Y. Spatial distribution of heavy metals $(\mathrm{Cu}, \mathrm{Pb}, \mathrm{Zn}$, and $\mathrm{Cd}$ ) in sediments of a coastal wetlands in eastern Fujian, China. Journal of Forestry Research, 26 (3), 703,2015.

15. TAN Y., HE D.J., YOU W.B., WANG R., CAI J.B., WANG P., ZHAO L.L., JIAN L.Y., XIAO S.H. Spartina alterniflora morphological plasticity and biomass allocation in response to tidal gradient change in Mindong coastal wetlands. Chinese Journal of Applied \& Environmental Biology, 20 (5), 863,2014.

16. ZHENG X.Y., HE D.J., YOU W.B., QIN D.H., YOU H.M., WU L.Y., JI Z.R. Ecological security pattern and spatial development pattern in Mindong region. Journal of Chongqing Normal University, 30 (02), 108, 2013.

17. YANG Y. The best breakthrough of the present study on the earth system science - a trial discussion on the theory frame building of coastal zones. Progress in Geography, 17 (1), 73,1998.

18. SUN C.Z., SUN B., GUO J.K., WANG Z.Y., BO L.I., LIUK. Measurement of land range and spatial-temporal difference analysis of coastal zone in Liaoning Province 
based on the "Lake Effect" model. Scientia Geographica Sinica, 29 (2), 199, 2015.

19. BUREAU N.S. Ningde Statistical Yearbook; China Statistics Press: Beijing, China, 1, 2000 [In Chinese].

20. BUREAU N.S. Ningde Statistical Yearbook; China Statistics Press: Beijing, China, 1, 2009 [In Chinese].

21. JIAN P., ZHAO M., GUO X., PAN Y., LIU Y. Spatialtemporal dynamics and associated driving forces of urban ecological land: a case study in Shenzhen City, China. Habitat International, 60, 81, 2017.

22. HÄRDLE W.K., HLÁVKA Z. Canonical correlation analysis. Journal of Financial Economic Policy, 6 (2), 179, 2012.

23. HARDOON D.R., SZEDMAK S., SHAWE-TAYLOR J. Canonical correlation analysis: an overview with application to learning methods. Neural Computation, 16 (12), 2639, 2004.

24. OU W.X., GAO J.H., ZHU H.Y., YANG G.S. The fuzzy comprehensive evaluation of water resource value on the coastal zone of northern Jiangsu. Economic Geography, 26 (4), 639, 2006.
25. ZHANG M., ZHU H.Y., HE S.J. An application of canonical correlation analysis to research on land-use patterns - taking Bohai Rim as an example. Geographical Research, 3 (1), 27,2001.

26. DU J.F., THILL J.C., PEISER R.B., FENG C. Urban land market and land-use changes in post-reform China: acase study of Beijing. Landscape \& Urban Planning, 124 (4), $118,2014$.

27. WU C.L., WANG Q., DONG Z., CHEN W.H. Land use/ cover change and its driving forces in coastal zone of Fujian Province. Bulletin of Soil and Water Conservation, 38 (3), 318, 2018.

28. HAN L., HOU X.Y., ZHU M.M. Study on the temporalspatial characters of land use change in the costal zone of America in the latter half of the $20^{\text {th }}$ century. World Regional Studies, 19 (2), 42, 2010.

29. WANG Y., JIA X.B., ZHANG W.G., FANG S.B., YAO Y.H., AN S.Q. Land use change and analysis on the driving forces in the coastal zone of Jiangsu. Resources and Environment in the Yangtze Basin, 19 (Z1), 7, 2010. 